\title{
DERMOID CYST OF INGUINAL CANAL MASQUERADING AS IRREDUCIBLE INGUINAL HERNIA: A CASE REPORT WITH REVIEW OF LITERATURE
}

Chandrakant R. Kesari, S. Lakkanna, Rohan Shetty, Preethamraj, Ashok. A.

1. Senior Resident. Department of General Surgery, Employee's State Insurance Corporation Medical College And Post Graduate Institute of Medical Sciences And Research, Rajajinagar, Bangalore, Karnataka.

2. Professor \& HOD. Department of General Surgery, Employee's State Insurance Corporation Medical College And Post Graduate Institute of Medical Sciences And Research, Rajajinagar, Bangalore, Karnataka.

3. Senior Resident. Department of General Surgery, Employee's State Insurance Corporation Medical College And Post Graduate Institute of Medical Sciences And Research, Rajajinagar, Bangalore, Karnataka.

4. Senior Resident. Department of General Surgery, Employee's State Insurance Corporation Medical College And Post Graduate Institute of Medical Sciences And Research, Rajajinagar, Bangalore, Karnataka.

5. Post Graduate. Department of General Surgery, Employee's State Insurance Corporation Medical College And Post Graduate Institute of Medical Sciences And Research, Rajajinagar, Bangalore, Karnataka.

\section{CORRESPONDING AUTHOR:}

Chandrakant R. Kesari,

Senior Resident, Department Of General Surgery,

ESICMC \& PGIMSR,

Rajajinagar, Bangalore.

E-mail: chandrukesari@gmail.com

Ph: 0091 9964119678, 080-23325130/23320271

ABSTRACT: INTRODUCTION: Dermoid cysts are common developmental anomalies occurring along embryonic fusion lines. Occurrence of this in inguinal region is rare and imposes diagnostic challenge as it confuses the clinician as irreducible inguinal hernia. CASE REPORT: Fifty years male patient presented with irreducible left inguinal hernia. Exploration of the left inguinal canal revealed a cyst $(7 \mathrm{~cm} \times 5 \mathrm{~cm})$ in the floor of the inguinal canal separated from the cord structures. The cyst was opened and foul smelling muddy paste like material came out. Cyst was completely excised. The histopathology was consistent with a dermoid cyst. The patient is doing well at five month follow up. CONCLUSION: Inguinal dermoid cyst mimicking irreducible hernia is rare but possible entity. If such cyst is encountered during hernia operation, complete excision is to be contemplated.

KEYWORDS: Dermoid Cyst, Inguinal Canal, Hernia

INTRODUCTION: Dermoid cysts are developmental lesions occurring along the line of embryonic fusion [1]. Common sites include supraorbital region of forehead and midline [1]. Dermoid cyst of anterior abdominal wall is rare. Literature review revealed only six cases of inguinal dermoid till date [Table 1].We report a case with review of literature.

CASE REPORT: Fifty years male patient presented with a swelling in left groin since last five years. The swelling was progressive in nature. There is no history of change in size or shape of the swelling on coughing or straining. Physical examination revealed a left sided inguinal swelling. The swelling was confined to inguinal region. It was elliptical shaped and measured 7 centimeters in its horizontal axis. Cough impulse was absent. The swelling was doughy on palpation. It was irreducible. Abdominal and per rectal examinations were within normal limits. 
A clinical diagnosis of Irreducible left inguinal hernia was made and an elective inguinal hernioplasty was planned.

Laboratory investigations reveled a hemoglobin of $12 \mathrm{~g} \%$, WBC10,000/cmm (N 60\%, L $30 \%$, E 7\%), blood sugar (105 g/dl), urea (22mg \%), creatinine (0.8). Chest Xray and ECG were within normal limits.

Exploration of the left inguinal canal revealed a cyst $(7 \mathrm{~cm} \times 5 \mathrm{~cm})$ in the floor of the inguinal canal separate from the cord structures (Figure 1). The cyst extended from the deep ring laterally to pubic tubercle medially. No direct or indirect sac could be detected. The cyst was opened and foul smelling muddy paste like material (Figure 2) came out which was evacuated. Cyst was completely excised (Figure 3) and sent for histopathology. The post operative recovery was uneventful and the patient was discharged on 10th post operative day after stitch removal.

Histopathology revealed a thin walled cystic lining composed of keratinized squamous epithelial cells. Underlying layers contained blood vessels, hair follicles, ecrine and apocrine glands. The above findings were consistent with a dermoid cyst.

The patient is doing well at 5 months of follow up

DISCUSSION: Hernia is the commonest inguinal swelling. Other common swellings include undescended testes, lipoma or hydrocele of spermatic cord. Rare inguinal swellings include preperitoneal lipoma, supernumerary pectineus bursa, haemorrhage into internal oblique muscle, round ligament angioma, pedunculated uterine fibromyoma, inguinal endometriosis and thrombophlebitis [5].

Dermoid cyst as a cause of inguinal swelling is rare. A search of English medical databases, using key words dermoid cyst and inguinal mass, revealed six case reports of inguinal dermoid till date (Table 1$)[2,3,4,8]$. Of the six patients three were female $[2,3]$ and three male [4]. Four patients were below 30 years [3,4] of age and the fifth patient was 72 years of age [2] and sixth 48 years of age [8]. The duration of the swelling varied from 1 to 4 years. The swellings were provisionally diagnosed as inguinal hernia [2, 4], lipoma [3] and cyst of the round ligament respectively. Dermoid cyst was revealed peroperatively and confirmed histopathologically. A fifth patient had dermoplastic repair of inguinal hernia and later developed inclusion dermoid [7]. This procedure is obsolete and as such does not need further elaboration.

Dermoid cysts may be teratomatous or non teratomatous benign malformations $[3,4,5]$. Non teratomatous dermoids are common in the inguinal canal. Grossly the excised tumour may be mistaken for a sebaceous cyst or epidermoids. The microscopic presence of skin along with its appendages and sebaceous gland differentiates them from epidermoids and sebaceous cyst which have stratified squamous epithelium surrounded by fibrous tissue forming their wall [2, $3,4]$. The absence of tissues foreign to the part differentiates it from a true dermoid found elsewhere. The contents of the cyst have been reported as tan colored keratin resulting from accumulation of stratum corneum $[4,8]$.

Diagnosis is often mistaken clinically as irreducible inguinal hernia. Complications of the cyst which resembles obstructed or incarcerated inguinal hernia include inflammation and hemorrhage [4]. The cyst may sometimes lead to compression of adjacent organs causing retention of urine and bowel obstruction [4]. Possibility of malignant degeneration exists especially in women with dermoid cysts arising from round ligament [6]. Tumour markers like 
alpha fetoprotein and beta chorionic gonadotropin estimation are helpful to monitor treatment and recurrence [6].

Surgical excision is the treatment of choice [1-8].

CONCLUSION: Inguinal dermoid cyst is rare. If encountered complete excision is to be contemplated in order to avoid complications like inflammation, hemorrhage and rarely malignant degeneration.

ACKNOWLEDGMENTS: The Authors are grateful to Dr. B. Rajeev Shetty (Dean), and Dr. S. L. Vig (Medical Superintendent) and my other colleagues of Department of general surgery for their support. They are also grateful to the patient for providing us the informed consent to communicate the observations as a case report and review of literature.

CONSENT: Written informed consent was obtained from the patient for publication of this manuscript and accompanying images.

COMPETING INTEREST: The authors declare that they have no competing interests.

\section{REFERENCES}

1. Genetzakis M, Lagoudianakis EE, Papadima A, Tsekouras DK, Markogiannakis H, Filis K, Manouras A. Inguinal dermoid cyst of the round ligament. A case report and review of the literature. Clin Exp Obstet Gynecol 2006;33:24951.

2. Dermoid cyst of the inguinal canal simulating a strangulated inguinal hernia. Brightmore T. Br J Clin Pract 1971;25:191.

3. Dermoid cyst of the inguinal canal. Ashraf SM, Ansari BA, Iqbal N, Ansari A. J Indian Med Assoc 1985;83:1256.

4. Inguinal dermoid cyst presenting as an incarcerated inguinal hernia. Leeming $\mathrm{R}$, Olsen M, Ponsky JL. J Pediatr Surg 1992;27:1178.

5. Farrands PA, Taylor I. Unusual groin swellings. Postgrad. Med. J. 1984;60;30911.

6. Khvorostov ED, Zakharchenko IuB, Tomin MS. Dermoid cyst of inguinal channel: review of the literature and clinical Observation. Klin Khir 2008;3:202.

7. Doctor HG, Talwalkar MG, Raichur BS. Inclusion dermoid cyst following repair of hernia with full thickness skin graft. Report of a case and review of the literature. J Int Coll Surg 1963;40:1096.

8. Das S, De D, Das D,Sarkar S. Inguinal Dermoid Cyst Masquerading As Irreducible Inguinal Hernia: Case Report. International Journal of Case Reports And Images 2012;3(11):*****. 
TABLE 1: PUBLISHED CASES REPORTS OF INGUINAL DERMOID

\begin{tabular}{|c|c|c|c|c|c|c|}
\hline YEAR & AUTHOR & JOURNAL & $\begin{array}{l}\text { AGE } \\
\text { (yrs) }\end{array}$ & SEX & $\begin{array}{l}\text { PROVISIONAL } \\
\text { DIAGNOSIS }\end{array}$ & $\begin{array}{l}\text { DURATION OF } \\
\text { MASS }\end{array}$ \\
\hline 1963 & $\begin{array}{l}\text { Doctor HG } \\
\text { et } \mathrm{al}^{7}\end{array}$ & J Int Coll Surg & \multicolumn{4}{|c|}{$\begin{array}{l}\text { Inclusion dermoid cyst following repair of hernia } \\
\text { with full thickness skin graft }\end{array}$} \\
\hline 1971 & $\begin{array}{l}\text { Brightmore } \\
2\end{array}$ & BJCP & 72 & $\mathrm{~F}$ & $\begin{array}{l}\text { Strangulated } \\
\text { Hernia }\end{array}$ & $4 y r s$ \\
\hline 1985 & $\begin{array}{l}\text { Asfraf et al } \\
3\end{array}$ & JIMA & 20 & $\mathrm{~F}$ & Lipoma & $2 y r s$ \\
\hline 1992 & $\begin{array}{l}\text { Leeming et } \\
\text { al } 4\end{array}$ & J Paed Surg & 18 & $\mathrm{M}$ & $\begin{array}{l}\text { Incarcerated } \\
\text { Hernia }\end{array}$ & $1 \mathrm{yrs}$ \\
\hline 2006 & $\begin{array}{l}\text { Genetzakis } \\
\text { M } \\
\text { et al }^{1}\end{array}$ & $\begin{array}{ll}\text { Clin } & \text { Exp } \\
\text { Obstet } & \\
\text { Gynecol } & \end{array}$ & 27 & $\mathrm{~F}$ & $\begin{array}{l}\text { Cyst Of Round } \\
\text { Ligament }\end{array}$ & $4 y r s$ \\
\hline 2012 & Das et $\mathrm{al}^{8}$ & IJCRI & 48 & $\mathrm{M}$ & Irreducible Hernia & $4 y r s$ \\
\hline $\begin{array}{l}2013 \\
\text { (present } \\
\text { case) }\end{array}$ & Kesari et al & JEMDS & 50 & M & $\begin{array}{l}\text { Irreducible Inguinal } \\
\text { Hernia }\end{array}$ & $5 y r s$ \\
\hline
\end{tabular}

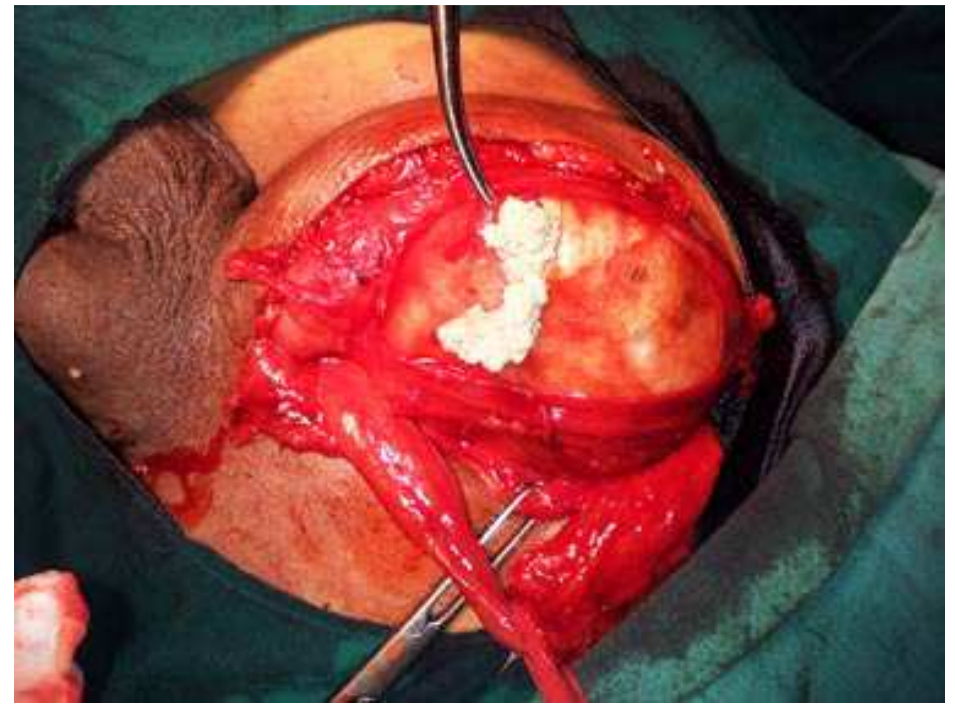

figure 1;cyst in floor of inguinal canal,seperated from cord structures 


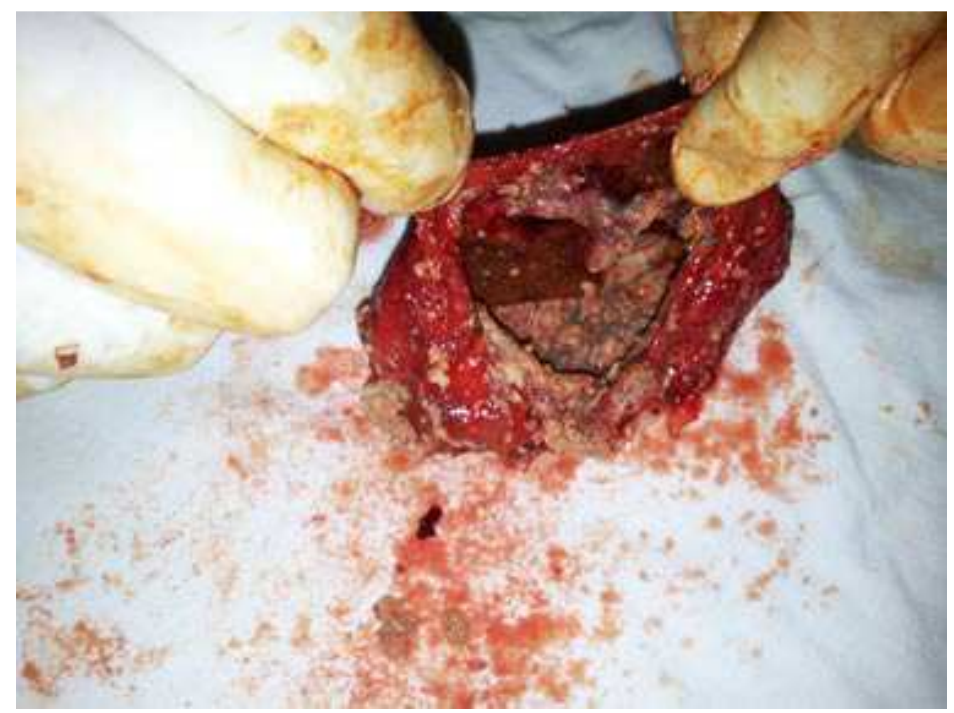

figure 2;cyst cavity from which foul smelling paste like material evacuated

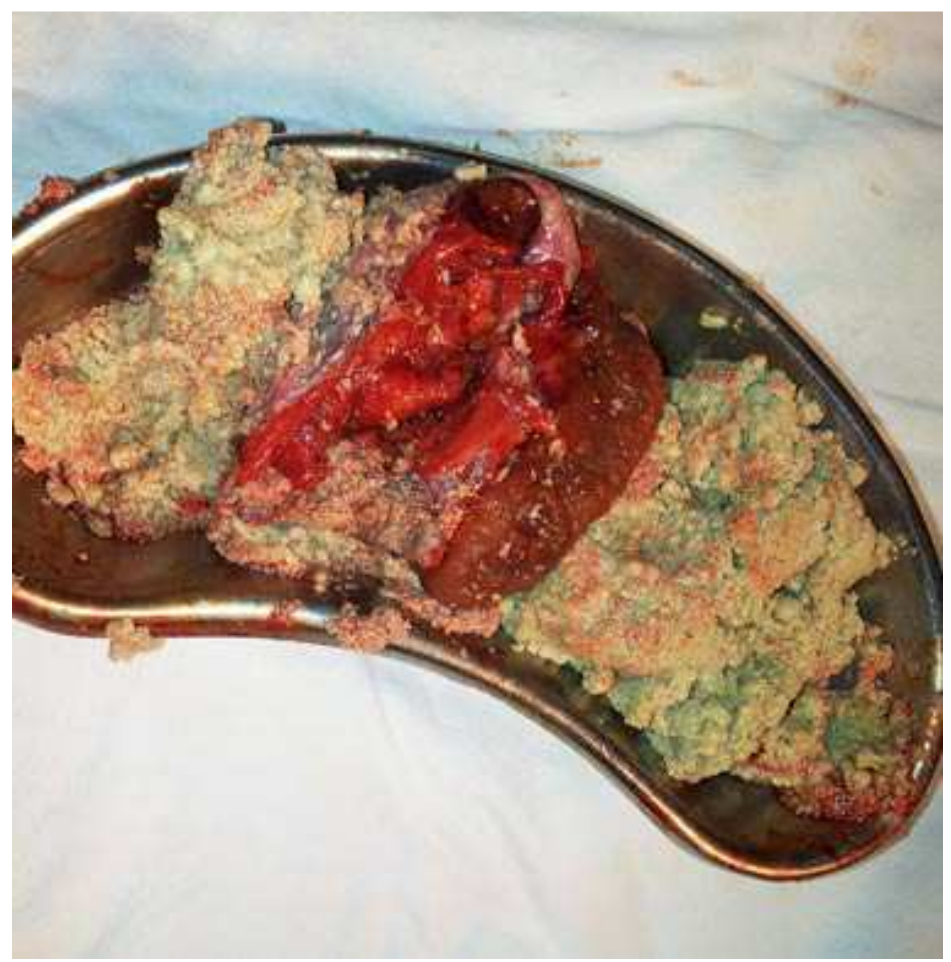

figure 3;completely excised cyst with paste like material 